\title{
Irish Post-crisis Migratory and Demographic Patterns
}

\section{Catherine Piola}

\section{Q OpenEdition \\ 1 Journals}

\section{Electronic version}

URL: http://journals.openedition.org/etudesirlandaises/4733

DOI: 10.4000/etudesirlandaises.4733

ISSN: 2259-8863

\section{Publisher}

Presses universitaires de Rennes

\section{Printed version}

Date of publication: 15 December 2015

Number of pages: $45-60$

ISBN: 978-2-7535-4366-9

ISSN: 0183-973X

\section{Electronic reference}

Catherine Piola, «Irish Post-crisis Migratory and Demographic Patterns », Études irlandaises [Online], 40-2 | 2015, Online since 15 December 2017, connection on 21 April 2019. URL : http://

journals.openedition.org/etudesirlandaises/4733; DOI : 10.4000/etudesirlandaises.4733 


\title{
Irish Post-crisis Migratory and Demographic Patterns
}

\author{
Catherine Piola \\ Université Paris-Dauphine
}

Abstract

Between 2008 and 2009, the Irish economic crisis directly impacted migratory flows, the very ones which had been deeply modified during the boom years. As was expected, the crisis triggered the return of some emigration flows which need to be quantified and qualified. Has it also reduced the in-coming flows of foreign residents and in what way will these migrations change the Irish population in the middle and long term? The following article answers this double question and provides the starting points for a further analysis of the topic as new data become available.

Keywords : Ireland, crisis, emigration, immigration, Irish population

\section{Résumé}

Entre 2008 et 2014, la crise économique irlandaise a eu un impact direct sur les flux migratoires, ceux-là mêmes qui avaient été fortement modifiés durant la période de forte expansion. Ainsi, comme on pouvait sy attendre, la crise a entraîné la reprise de l'émigration et il s'agit de quantifier et qualifier ces mouvements. A-t-elle dans le même temps réduit l'afflux de résidents étrangers sur le territoire et en quoi ces mouvements de population transforment-ils à court et moyen terme la composition de la population irlandaise? L'article apportera des éléments de réponse à ces interrogations en dressant un premier état des lieux afin de poser les jalons d'une analyse plus détaillée, au fur et à mesure que de nouvelles données seront disponibles.

Mots clés : Irlande, crise, émigration, immigration, population irlandaise

This article intends to outline the impact of the 2008 economic crisis on the population of the Republic of Ireland by introducing the main migratory features and challenges of the post-crisis period and by analyzing outlining its effect on the population as a whole. Several questions can indeed be asked to measure the changes the economic crisis has brought about in within the Irish population, the growth and nature of which had already noticeably transformed during the boom period. Most of these changes focus on population flows, their size and composition. Have new patterns emerged in the wake of the economic downturn? Who has been most affected by the crisis and in what ways? Who left the country and who intends to remain? In order to answer these questions, migratory patterns 
between 2008 and 2015 are considered thanks to the data available in collected by the censuses of the population and the regular Central Statistics Office figures on population flows. They are presented in the form of 12 tables.

This paper tackles migration issues as it is naturally and logically assumed that any economic crisis triggers population out-flows due to a contracted labour market resulting in fewer jobs or other opportunities. In the case of Ireland, where emigration has been part of the history of the country for so long and where immigration had only recently come into existence, the scale of such population flows needs to be measured to determine what effect the crisis has had. It is also expected that immigrants having settled in the Republic during the Celtic Tiger era, may have decided to look for more economically attractive prospects somewhere else. These assumptions need to be questioned with the most recent data available. Finally, the long term impact of such changes will be considered, issues such as naturalisation or cultural diversity will be explored outlined in the uncertain context of a recovery period.

\section{The pre-2008 migratory patterns: the persistence of departures and the large in-flow of non nationals and returnees}

While The Republic of Ireland enjoyed several years of extraordinary economic expansion, from the mid-1990s to 2008, its demography recorded an equally major change as not only an unprecedented inflow of non-national migrants developed, mainly to suit the labour market's increasing needs, but also because a number of Irish emigrants decided to avail themselves of the opportunity of a thriving economy to return to the motherland. Table 1 illustrates the scale of such flows. Emigration figures are also indicated as they varied in direct connection with the economic outlook.

\begin{tabular}{|c|c|c|c|c|c|c|c|c|c|c|c|c|c|}
\hline Year & 1995 & 1996 & 1997 & 1998 & 1999 & 2000 & 2001 & 2002 & 2003 & 2004 & 2005 & 2006 & 2007 \\
\hline Imm. & 31.2 & 39.2 & 44.5 & 46 & 48.9 & 52.6 & 59 & 66.9 & 60 & 58.5 & 84.6 & 107.8 & 151.1 \\
\hline Emi. & 33.1 & 31.2 & 25.3 & 28.6 & 31.5 & 26.6 & 26.2 & 25.6 & 29.3 & 26.5 & 29.4 & 36 & 46.3 \\
\hline
\end{tabular}

Table 1: Immigration to and emigration from the Republic (000 persons), 1995 to 2006 (Population and Migration Estimates, Dublin, Central Statistics Office, September 2012, p. 4.)

In the mid-1990s, migratory flows in the Irish Republic were almost balanced, resulting in a net migration which became positive during the year 1995 and remained so until 2010. Immigration volumes tripled between 1995 and 2006 and peaked in 2007. The 2004 European Union enlargement and the Republic's non-restrictive policy on new European Union citizens' circulation largely 
explain this surplus, mostly made of workers attracted to the then thriving Irish economy. Returning Irish migrants were enumerated as part of the immigrants, with figures ranging from 16,000 to 21,000 a year in the period 2000 to 2007 . They accounted for less than a quarter of the total number of immigrants for the 2005 to 2008 period. This modest share nonetheless increased the volume of incoming population, contributing to the positive net migration balance.

The table also shows that even during the peak immigration years, emigration flows did not dry up as between 1995 and 2007 close to 370,000 persons left the country. Emigration was nevertheless at its lowest in the early 2000s, representing an annual loss of $0.7 \%$ at its lowest levels. Up to the 1990 s, it is assumed that most of the emigrants were Irish citizens, but the data available not being precise enough as to the nationality of emigrants, it is impossible to quantify their share up to 2002. Regardless of the nationalities of emigrants, it needs to be remembered that, in 2007 for example, when the country attracted a large number of residents from abroad, one resident was leaving for every three newcomers.

\section{The most visible effect of the crisis: out-migration flows}

The following graph shows the volume of emigrants to the Republic in the post-crisis period. As can be expected, the Irish economic downturn triggered a new wave of emigration. This is quantified first and then analysed further and in relation to previous years and other criteria.

\begin{tabular}{|l|c|c|c|c|c|c|c|c|c|}
\hline Year & 2006 & 2007 & 2008 & 2009 & 2010 & 2011 & 2012 & 2013 & 2014 \\
\hline Emigration & 36 & 46.3 & 49.2 & 72 & 69.2 & 80.6 & 87.1 & 89 & 81.9 \\
\hline Net migration & 71.8 & 104.8 & 64.3 & 1.6 & -27.5 & -27.4 & -34.4 & -33.1 & -21.4 \\
\hline
\end{tabular}

Table 2: Emigration from the Republic (000 persons) and net migration (000 persons), 2006 to 2014 (Measuring Ireland's Progress 2013, Dublin, Central Statistics Office, February 2015, Table 1.3 and Population and Migration Estimates, Dublin, Central Statistics Office, August 2014)

The scale of the out-going flow is the first feature which has to be highlighted. Indeed, emigration, which had remained below the threshold of 30,000 from 1997 to 2005 (except for 1999 and its 31,500 emigrants), reached almost 50,000 in 2008 and has remained in the 80,000 range since 2011, with a record high of 89,000 in 2013 . The correlation between economic downturn and emigration is unsurprisingly strong. The net migration balance has turned negative since 2010 as a result of the re-emergence of such patterns. However the scale of such outflows remains below what was recorded in the late 1980s. Indeed, with losses reaching about 43,000 in 1988 and 1989, the 2014 net migration rate is not the 
worst ever recorded as it accounts for $0.4 \%$ of the 2014 total population, whereas the figure was $1.18 \%$ in 1988 .

Beyond figures, the early $21^{\text {st }}$ century emigration calls for a qualitative analysis. In order to refine this profile, let us consider the origins, age groups and occupations of those who have left the Republic since the crisis.

\begin{tabular}{|l|c|c|c|c|c|c|c|c|c|c|}
\hline & 2006 & 2007 & 2008 & 2009 & 2010 & 2011 & 2012 & 2013 & 2014 & $\begin{array}{c}\text { Male/ } \\
\text { Female }\end{array}$ \\
\hline Irish & $\begin{array}{c}15.3 \\
(42.5 \%)\end{array}$ & $\begin{array}{c}12.9 \\
(27.8 \%)\end{array}$ & $\begin{array}{c}13.1 \\
(26.7 \%)\end{array}$ & $\begin{array}{c}19.2 \\
(26.6 \%)\end{array}$ & $\begin{array}{c}28.9 \\
(41.7 \%)\end{array}$ & $\begin{array}{c}42 \\
(52.1 \%)\end{array}$ & $\begin{array}{c}46.5 \\
(53.3 \%)\end{array}$ & $\begin{array}{c}50.9 \\
(57.1 \%)\end{array}$ & $\begin{array}{c}40.7 \\
(49.7 \%)\end{array}$ & $22.7 / 18$ \\
\hline British & $\begin{array}{c}2.2 \\
(6.1 \%)\end{array}$ & $\begin{array}{c}3.7 \\
(7.9 \%)\end{array}$ & $\begin{array}{c}3.7 \\
(7.5 \%)\end{array}$ & $\begin{array}{c}3.9 \\
(5.4 \%)\end{array}$ & $\begin{array}{c}3 \\
(4.3 \%)\end{array}$ & $\begin{array}{c}4.6 \\
(5.7 \%)\end{array}$ & $\begin{array}{c}3.5 \\
(4 \%)\end{array}$ & $\begin{array}{c}3.9 \\
(4.3 \%)\end{array}$ & $\begin{array}{c}2.7 \\
(3.3 \%)\end{array}$ & $1.6 / 1.1$ \\
\hline $\begin{array}{l}\text { Rest } \\
\text { EU15 }\end{array}$ & $\begin{array}{c}5.1 \\
(14.1 \%)\end{array}$ & $\begin{array}{c}8.9 \\
(19.2 \%)\end{array}$ & $\begin{array}{c}6 \\
(12.2 \%)\end{array}$ & $\begin{array}{c}7.4 \\
(10.2 \%)\end{array}$ & $\begin{array}{c}9 \\
(13 \%)\end{array}$ & $\begin{array}{c}10.2 \\
(12.6 \%)\end{array}$ & $\begin{array}{c}11.2 \\
(12.8 \%)\end{array}$ & $\begin{array}{c}9.9 \\
(11.1 \%)\end{array}$ & $\begin{array}{c}14 \\
(17 \%)\end{array}$ & $5.7 / 8.3$ \\
\hline EU12** & $\begin{array}{c}7.2 \\
(20 \%)\end{array}$ & $\begin{array}{c}12.6 \\
(27.2 \%)\end{array}$ & $\begin{array}{c}17.2 \\
(35.1 \%)\end{array}$ & $\begin{array}{c}30.5 \\
(42.3 \%)\end{array}$ & $\begin{array}{c}19 \\
(27.4 \%)\end{array}$ & $\begin{array}{c}13.9 \\
(17.2 \%)\end{array}$ & $\begin{array}{c}14.8 \\
(17 \%)\end{array}$ & $\begin{array}{c}14 \\
(15.7 \%)\end{array}$ & $\begin{array}{c}10.1 \\
(12.3 \%)\end{array}$ & $6.1 / 4$ \\
\hline $\begin{array}{l}\text { Rest/ } \\
\text { world }\end{array}$ & $\begin{array}{c}6.2 \\
(17.2 \%)\end{array}$ & $\begin{array}{c}8.2 \\
(17.7 \%)\end{array}$ & $\begin{array}{c}9 \\
(18.3 \%)\end{array}$ & $\begin{array}{c}11 \\
(15.2 \%)\end{array}$ & $\begin{array}{c}9.3 \\
(13.5 \%)\end{array}$ & $\begin{array}{c}9.9 \\
(12.2 \%)\end{array}$ & $\begin{array}{c}11.1 \\
(12.7 \%)\end{array}$ & $\begin{array}{c}10.3 \\
(11.5 \%)\end{array}$ & $\begin{array}{c}14.4 \\
(17.5 \%)\end{array}$ & $5.9 / 8.5$ \\
\hline Total & 36 & 46.3 & 49 & 72 & 69.2 & 80.6 & 87.1 & 89 & 81.9 & $42 / 39.9$ \\
\hline
\end{tabular}

** EU 12 until 2013, EU13 for 2014 as Croatia joined the EU in July 2013

Table 3: Emigration by nationality and area of origin, 2006 to 2014, classified by sex for 2014 (000's and \% of total) (Population and Migration Estimates, Table 2, Dublin, Central Statistics Office, August 2013 and 2014)

As the total number of emigrants swelled over the period studied, by a factor of 2.5 between 2006 and 2013, remaining over 80,000 since 2011, the table shows the extent to which this was not a uniform flow across the different nationalities and areas. The Irish were not the most numerous in the immediate aftermath of the crisis, in 2008 and 2009, but they have remained numerically the largest population hit by outflows, with a total of about 242,000 citizens between 2008 and 2014, that is to say $1.93 \%$ of the Republic's 2013 total population at its highest point. To put this into perspective, this represented a daily departure of 243 persons in 2013, a figure which was not significantly lower, 224 persons, in 2014. Since 2011, they have represented over one emigrant out of two, with a peak of 57\% in 2013 and with only a very slight decrease in 2014 . Their favorite destinations remained the UK for a quarter of them, the USA and more recently Australia with a temporary surge between 2010 and $2013^{1}$.

1. On average, about 10,000 people emigrated annually from Ireland to Australia between 2008 and 2010. The figure reached 13,400 in 2011, 18,200 in 2012 and 15,400 in 2013. It returned to more usual volumes in 2014 with 10,000 emigrants. This was partly the result of the Working Holiday Arrangement scheme. 
The Irish were numerically the largest emigrant group, with a total of $1 \%$ of the Irish citizens leaving their country in 2012, but their proportional representation among the different nationalities was not the highest. Indeed, $5.6 \%$ of the non-EU-foreign nationals residing in the State left the Republic in 2011. This group, made up of over 50 different nationalities, is the one which has maintained a steady outflow throughout the period.

The post-enlargement continental Europeans are the ones who showed have shown the highest mobility at the earliest signs of the crisis: they accounted for $35 \%$ and $42 \%$ of the total number of emigrants in 2008 and 2009, by far the largest group. It can be assumed that most of them had settled in the Republic between 2004 and 2007 and were therefore more adaptable to a new change than longer established foreign residents. Indeed, the pre-enlargement European citizens remained fewer than 10,000 until 2010.

It is to be noted that for all groups, the 2014 total figures remain rather high compared to the previous years. The Irish were still twice as many to emigrate in 2014 as they had been in 2009 and this is also true for the pre-enlargement continental Europeans. The non-European residents recorded the highest volume of emigrants ever in 2014. The slow recovery of the economy is undoubtedly one of the decisional factors for these migrants whose presence was almost exclusively linked to some employment prospects. The Irish unemployement rate was $4.6 \%$ in 2004 and remained low until 2008. It peaked at $15 \%$ in 2012. The rate of male emigrants, both for the Irish citizens and for the post-enlargement Europeans is to be considered in relation to the ailing, predominantly male economic sectors such as construction.

The correlation with the labour market can be traced in data on the agegroups, education attainments and economic status of the emigrants (see Table 4).

The document shows that pre-crisis emigration from the Republic was characterised by the young age of migrants, up to 2006 the 15-24 age group was the largest, accounting for up to $73 \%$ of the total number of emigrants, part of this group being made of students. From 2007 onward, with the exception of 2011, emigrants became more numerous in the 25-44 age group. The crisis hit young adults, many of them involved in the labour market. This is a predominantly male population. Throughout the period, the mature adult and senior emigrants remain relatively few but record slightly increasing proportions.

The most recent figures indicate a more evenly shared and less predominantly male group of emigrants in the 15-44 age brackets. The proportion of children and young teenagers in some of the selected years highlights family emigration at its highest in volume and proportionately in 2014.

The education attainment profile of the emigrants is a feature which has recently been made available; the figures reveal two main groups of emigrants: 
those who only have secondary school education and those who have attended a third level course.

\begin{tabular}{|l|c|c|c|c|c|c|c|c|c|}
\hline & 1995 & $\mathrm{M}$ & 2002 & 2006 & 2008 & $\mathrm{M}$ & 2010 & 2014 & $\mathrm{M}$ \\
\hline $0-14$ & $\begin{array}{c}1.2 \\
(3.6 \%)\end{array}$ & 50 & $\begin{array}{c}2.5 \\
(9.7 \%)\end{array}$ & $\begin{array}{c}2.2 \\
(6 \%)\end{array}$ & $\begin{array}{c}1.6 \\
(3.2 \%)\end{array}$ & 42 & $\begin{array}{c}2 \\
(2.9 \%)\end{array}$ & $\begin{array}{c}6 \\
(7.3 \%)\end{array}$ & 36 \\
\hline $15-24$ & $\begin{array}{c}22.6 \\
(68 \%)\end{array}$ & 52 & $\begin{array}{c}18.7 \\
(73 \%)\end{array}$ & $\begin{array}{c}15.9 \\
(44 \%)\end{array}$ & $\begin{array}{c}17.8 \\
(36 \%)\end{array}$ & 54 & $\begin{array}{c}26.7 \\
(38.5 \%)\end{array}$ & $\begin{array}{c}33.5 \\
(41 \%)\end{array}$ & 47 \\
\hline $25-44$ & $\begin{array}{c}8.5 \\
(25.6 \%)\end{array}$ & 64 & $\begin{array}{c}3.1 \\
(12 \%)\end{array}$ & $\begin{array}{c}14.1 \\
(39 \%)\end{array}$ & $\begin{array}{c}24 \\
(48.6 \%)\end{array}$ & 62 & $\begin{array}{c}36.5 \\
(52.7 \%)\end{array}$ & $\begin{array}{c}37.6 \\
(46 \%)\end{array}$ & 59 \\
\hline $45-64$ & $\begin{array}{c}0.8 \\
(2.4 \%)\end{array}$ & 37 & $\begin{array}{c}0.1 \\
(0.4 \%)\end{array}$ & $\begin{array}{c}2.1 \\
(5.8 \%)\end{array}$ & $\begin{array}{c}2.9 \\
(5.8 \%)\end{array}$ & 75 & $\begin{array}{c}2.9 \\
(4.2 \%)\end{array}$ & $\begin{array}{c}3.4 \\
(4 \%)\end{array}$ & 41 \\
\hline $65+$ & $\begin{array}{c}0 \\
(0 \%)\end{array}$ & 50 & $\begin{array}{c}1.2 \\
(4.6 \%)\end{array}$ & $\begin{array}{c}1.7 \\
(4.7 \%)\end{array}$ & $3(6 \%)$ & 66 & $\begin{array}{c}1.1 \\
(1.5 \%)\end{array}$ & $\begin{array}{c}1.5 \\
(1.8 \%)\end{array}$ & 26 \\
\hline Total & $\begin{array}{c}33.1 \\
(100 \%)\end{array}$ & 53 & $\begin{array}{c}25.6 \\
(100 \%)\end{array}$ & $\begin{array}{c}36 \\
(100 \%)\end{array}$ & $\begin{array}{c}49.3 \\
(100 \%)\end{array}$ & 60 & $\begin{array}{c}69.2 \\
(100 \%)\end{array}$ & $\begin{array}{c}81.9 \\
(100 \%)\end{array}$ & 51.2 \\
\hline
\end{tabular}

** EU 12 until 2013, EU13 for 2014 as Croatia joined the EU in July 2013

Table 4: Age groups of emigrants (000s and \% of total), Male rates for selected years 1995 to 2014 (Population and Migration Estimates, Table 2, Dublin, Central Statistics Office, August 2013 and 2014)

\begin{tabular}{|l|c|c|c|c|c|c|}
\hline Education & 2009 & 2010 & 2011 & 2012 & 2013 & 2014 \\
\hline \multirow{2}{*}{ Secondary } & 31.6 & 26.7 & 30.1 & 31.5 & 37.7 & 27.6 \\
& $(45 \%)$ & $(39.7 \%)$ & $(40 \%)$ & $(38.3 \%)$ & $(45.8 \%)$ & $(36 \%)$ \\
\hline \multirow{2}{*}{ Post Leaving Cert. } & 6.7 & 7.1 & 6.2 & 6.8 & 6.7 & 6.3 \\
& $(9.6 \%)$ & $(10.5 \%)$ & $(8.2 \%)$ & $(8.2 \%)$ & $(8 \%)$ & $(8 \%)$ \\
\hline \multirow{2}{*}{3 rd level } & 24.4 & 27.9 & 35.8 & 39 & 35 & 35.3 \\
& $(35 \%)$ & $(41.5 \%)$ & $(47.4 \%)$ & $(47.4 \%)$ & $(42.5 \%)$ & $(46.5 \%)$ \\
\hline \multirow{2}{*}{ Not stated } & 7 & 5.4 & 3.3 & 4.8 & 2.9 & 6.7 \\
& $(10 \%)$ & $(8 \%)$ & $(4.3 \% \%)$ & $(5.8 \% \%)$ & $(3.5 \%)$ & $(8.8 \%)$ \\
\hline \multirow{2}{*}{ Total } & 69.7 & 67.2 & 75.4 & 82.2 & 82.2 & 75.9 \\
& $(100 \%)$ & $(100 \%)$ & $(100 \%)$ & $(100 \%)$ & $(100 \%)$ & $(100 \%)$ \\
\hline
\end{tabular}

Table 5: Emigrants' education attainment, aged 15 and over, 2009 to 2014 (000s and percentage of the emigrant population) (Population and Migration Estimates, Table 5, Dublin, Central Statistics Office, August 2014)

Since 2011, the number of highly educated emigrants has reached an annual volume of over 35,000 persons, that is to say 10,000 more each year compared to the 2009 figure. Qualified and possibly experienced workers, Irish and non-national, thus form the largest group of those who have decided to leave the Republic since 2010. Those who have reached more than a secondary edu- 
cation level have represented just over 41,000 individuals in 2014 and in 2013; although the absolute figure may sound negligible, it means they account for close to $1 \%$ of the total population of the Republic, who have not been and will not be of any benefit to the Irish labour force. This may not be a case of massive brain drain, as more precise figures are needed to assess the validity of the term, but rather a trickle which, in the medium to long term, could have the effect of a hemorrhage.

The figures for 2009 indicate a larger share of emigrants who only completed their secondary education. The share of this group within the total emigrant population fluctuated moderately but never below the 2014 figure of $36 \%$. These, who have a basic level of education and therefore often occupy unskilled positions, are still part of the emigration flows and more data would be needed to refine the profile of this sizeable group. So far, such data is has not been made available.

Finally, the emigrants' economic status is an interesting indicator of the possible motivation for the decision to leave the country.

\begin{tabular}{|l|c|c|c|c|c|c|c|}
\hline Status & 2009 & 2010 & 2011 & 2012 & 2013 & 2014 & $\mathrm{M}$ \\
\hline At work & $\begin{array}{c}41.3 \\
(59.2 \%)\end{array}$ & $\begin{array}{c}31.1 \\
(46.2 \%)\end{array}$ & $\begin{array}{c}36.2 \\
(48 \%)\end{array}$ & $\begin{array}{c}38.5 \\
(46.8 \%)\end{array}$ & $\begin{array}{c}36.5 \\
(44.4 \%)\end{array}$ & $\begin{array}{c}28.9 \\
(38 \%)\end{array}$ & 50 \\
\hline $\begin{array}{l}\text { Unem- } \\
\text { ployed }\end{array}$ & $\begin{array}{c}10.8 \\
(15.5 \%)\end{array}$ & $\begin{array}{c}16.4 \\
(24.4 \%)\end{array}$ & $\begin{array}{c}15.2 \\
(20 \%)\end{array}$ & $\begin{array}{c}18.6 \\
(22.6 \%)\end{array}$ & $\begin{array}{c}17.2 \\
(21 \%)\end{array}$ & $\begin{array}{c}12.3 \\
(16 \%)\end{array}$ & 65 \\
\hline Student & $\begin{array}{c}12.5 \\
(18 \%)\end{array}$ & $\begin{array}{c}14.2 \\
(21 \%)\end{array}$ & $\begin{array}{c}17.6 \\
(23 \%)\end{array}$ & $\begin{array}{c}19.5 \\
(23.7 \%)\end{array}$ & $\begin{array}{c}20.2 \\
(24.5 \%)\end{array}$ & $\begin{array}{c}29 \\
(38.2 \%)\end{array}$ & 51.3 \\
\hline Other & 5.1 & 5.5 & $\begin{array}{c}6.5 \\
(8.3 \%)\end{array}$ & $\begin{array}{c}5.5 \\
(6.7 \%)\end{array}$ & $\begin{array}{c}8.3 \\
(10 \%)\end{array}$ & $\begin{array}{c}5.7 \\
(7.5 \%)\end{array}$ & 43.8 \\
\hline Total & 69.7 & $\begin{array}{c}67.2 \\
(100 \%)\end{array}$ & $\begin{array}{c}75.4 \\
(100 \%)\end{array}$ & $\begin{array}{c}82.2 \\
(100 \%)\end{array}$ & $\begin{array}{c}82.2 \\
(100 \%)\end{array}$ & $\begin{array}{c}75.9 \\
(100 \%)\end{array}$ & \\
\hline
\end{tabular}

Table 6: Emigrants' economic status, aged 15 and over, 2009 to 2014, (000 persons and percentage of the emigrant population) and male emigrants in 2014 (\%) (Population and Migration Estimates, Table 6, Dublin, Central Statistics Office, August 2014)

Throughout the period, it is worth noting that the largest numbers of those who left were workers involved in the labour market. A total of 213,000 working emigrants left between 2009 and 2014. This questions the assumption according to which emigrants decide to leave the country because of rising unemployment. The lack of long term perspectives, promotion or improvement of working conditions is certainly also at play. Only qualitative surveying of these populations would allow a better understanding of their motivations. These emigrants accounted for the majority of those who left the country up to 2014. But not all emigrants were at work at the time of their departure. 
Students leaving the country were more and more numerous during the 20092014 period. Their soaring volumes, a total of 113,000 persons, as well as their increasing proportion, from $18 \%$ of the total number of emigrants to $38.2 \%$, make them the largest group of emigrants in 2014. Both groups, either students or workers, many of them well qualified and experienced, deprive the Irish society of their potential as a result of their decision to leave. Given the extent of the phenomenon and the small size of the Irish population, such outflows can be considered as a brain-drain phenomenon. Indeed, a part of these being highly educated, the term is appropriate in the post-2008 crisis in the Republic of Ireland.

Another group of emigrants not at work at the time of their departure was the unemployed. Their volumes fluctuated but remained high with a total of over 90,000 persons. Ironically, both groups contributed to the economic recovery of the country with their departures, either creating new opportunities when the positions they left were maintained, or else helping reduce the unemployment rate. Emigration did operate as a safety valve in the aftermath of the crisis, yet its effects on the unemployment rate and job opportunities seemed to have been rather limited as it has been slow to get nearer to the pre-2008 levels in spite of the departure of so many unemployed.

In the case of the Republic and the 2008 crisis, what also contributed to a balance between a shrinking economy and an adjusting labour force is the fact that during the post-crisis period, in-coming demographic flows did not stop.

\section{Despite a slowdown in flows, immigrants are still coming in}

It is usually expected that immigration should significantly shrink after an economic crisis as in-coming flows are partly triggered by or more generally sensitive to economic downturns. This proved to be the case after the 2008 crisis in Ireland as the flowing table shows, but only to some extent.

\begin{tabular}{|l|c|c|c|c|c|c|c|c|c|}
\hline Year & 2006 & 2007 & 2008 & 2009 & 2010 & 2011 & 2012 & 2013 & 2014 \\
\hline Imm. & 107.8 & 151.1 & 113.5 & 73.7 & 41.8 & 53.3 & 52.7 & 55.9 & 60.6 \\
\hline Net mig. & 71.8 & 104.8 & 64.3 & 1.6 & -27.5 & -27.4 & -34.4 & -33.1 & -21.4 \\
\hline
\end{tabular}

Table 7: Immigration to the Republic (000 persons) and net migration, 2006 to 2014 (Measuring Ireland's Progress, Table 1.3, Dublin, Central Statistics Office, 2013 and Population and Migration Estimates, Dublin, Central Statistics Office, August 2014)

The table traces how the immigration flows to Ireland reduced dramatically, from a pre-crisis peak in 2007 to its lowest volume in 2010. It then stabilised slightly at the rate of over 50,000 annual entries between 2011 and 2012, that 
is to say to about a third of its 2007 level, and picked up again from 2012 on. The initial major slowdown was expected, as the signal of an ailing economy does cause such rapid changes among ready-to-go immigrants. The fast return of incoming flows before the end of 2013 was more unexpected, as it was not motivated yet by the recovery of the economy. Such a subtle link between economic growth and in-coming flows needs to be better defined.

Qualifying immigration to Ireland in the post-crisis period has to be based on the same data as what was referred to for emigration flows in the previous section.

\begin{tabular}{|c|c|c|c|c|c|c|c|c|c|c|}
\hline & 2006 & 2007 & 2008 & 2009 & 2010 & 2011 & 2012 & 2013 & 2014 & $\begin{array}{l}\text { Male/ } \\
\text { Female } \\
000 \mathrm{~s}\end{array}$ \\
\hline Irish & $\begin{array}{c}18.9 \\
(17.5 \%)\end{array}$ & $\begin{array}{c}30.7 \\
(20.3 \%)\end{array}$ & $\begin{array}{c}23.8 \\
(21 \%)\end{array}$ & $\begin{array}{c}23 \\
(31.3 \%)\end{array}$ & $\begin{array}{c}17.9 \\
(42.7 \%)\end{array}$ & $\begin{array}{c}19.6 \\
(36.8 \%)\end{array}$ & $\begin{array}{c}20.6 \\
(39 \%)\end{array}$ & $\begin{array}{c}15.7 \\
(28 \%)\end{array}$ & $\begin{array}{c}11.6 \\
(19.1 \%)\end{array}$ & $5.5 / 6.1$ \\
\hline British & $\begin{array}{c}9.9 \\
(9.2 \%)\end{array}$ & $\begin{array}{c}4.3 \\
(2.8 \%)\end{array}$ & $\begin{array}{c}6.8 \\
(2.8 \%)\end{array}$ & $\begin{array}{c}3.9 \\
(5.3 \%)\end{array}$ & $\begin{array}{c}2.5 \\
(6 \%)\end{array}$ & $\begin{array}{c}4.1 \\
(7.7 \%)\end{array}$ & $\begin{array}{c}2.2 \\
(4.2 \%)\end{array}$ & $\begin{array}{c}4.9 \\
(8.7 \%)\end{array}$ & $\begin{array}{c}4.9 \\
(8 \%)\end{array}$ & $2 / 2.9$ \\
\hline $\begin{array}{l}\text { Rest } \\
\text { EU15 }\end{array}$ & $\begin{array}{c}12.7 \\
(11.8 \%)\end{array}$ & $\begin{array}{c}11.8 \\
(7.8 \%)\end{array}$ & $\begin{array}{c}9.6 \\
(8.5 \%)\end{array}$ & $\begin{array}{c}11.5 \\
(15.6 \%)\end{array}$ & $\begin{array}{c}6.2 \\
(14.8 \%)\end{array}$ & $\begin{array}{c}7.1 \\
(13.3 \%)\end{array}$ & $\begin{array}{c}7.2 \\
(13.6 \%)\end{array}$ & $\begin{array}{c}7.4 \\
(13.2 \%)\end{array}$ & $\begin{array}{c}8.7 \\
(14.3 \%)\end{array}$ & $4.3 / 4.3$ \\
\hline EU12** & $\begin{array}{c}49.9 \\
(46.3 \%)\end{array}$ & $\begin{array}{c}85.3 \\
(56.5 \%)\end{array}$ & $\begin{array}{c}54.7 \\
(48.2 \%)\end{array}$ & $\begin{array}{c}21.1 \\
(28.7 \%)\end{array}$ & $\begin{array}{c}9.3 \\
(22.2 \%) \\
\end{array}$ & $\begin{array}{c}10.1 \\
(18.9 \%)\end{array}$ & $\begin{array}{c}10.4 \\
(19.7 \%) \\
\end{array}$ & $\begin{array}{c}10.9 \\
(19.5 \%) \\
\end{array}$ & $\begin{array}{c}10 \\
(16.5 \%) \\
\end{array}$ & $4.8 / 5.2$ \\
\hline $\begin{array}{l}\text { Rest/ } \\
\text { world }\end{array}$ & $\begin{array}{c}16.4 \\
(15.2 \%) \\
\end{array}$ & $\begin{array}{c}19 \\
(12.6 \%) \\
\end{array}$ & $\begin{array}{c}18.6 \\
(16.4 \%) \\
\end{array}$ & $\begin{array}{c}14.1 \\
(19.2 \%) \\
\end{array}$ & $\begin{array}{c}6 \\
(13.3 \%) \\
\end{array}$ & $\begin{array}{c}12.4 \\
(23.3 \%) \\
\end{array}$ & $\begin{array}{c}12.4 \\
(23.5 \%) \\
\end{array}$ & $\begin{array}{c}17.1 \\
(30.6 \%) \\
\end{array}$ & $\begin{array}{c}25.5 \\
(42 \%) \\
\end{array}$ & $11.6 / 13.9$ \\
\hline Total & $\begin{array}{c}107.8 \\
(100 \%)\end{array}$ & $\begin{array}{c}151.1 \\
(100 \%)\end{array}$ & $\begin{array}{c}113.5 \\
(100 \%)\end{array}$ & $\begin{array}{c}73.7 \\
(100 \%)\end{array}$ & $\begin{array}{c}41.8 \\
(100 \%)\end{array}$ & $\begin{array}{c}53.3 \\
(100 \%)\end{array}$ & $\begin{array}{c}52.7 \\
(100 \%)\end{array}$ & $\begin{array}{c}55.9 \\
(100 \%)\end{array}$ & $\begin{array}{c}60.6 \\
(100 \%)\end{array}$ & $28.2 / 32.4$ \\
\hline
\end{tabular}

** EU 12 until 2013, EU13 for 2014 as Croatia joined the EU in July 2013

Table 8: Immigration by nationality and area of origin, 2006 to 2014, 000 persons, with percentage of total migration and classified by sex for 2014 (Population and Migration Estimates, Table 2, Dublin, Central Statistic Office, August 2013 and 2014)

In order to sketch a profile of the immigrants to Ireland since 2008, one first needs to distinguish between Irish (returning) migrants and non-nationals.

From the mid-1990s to 2006, the flow of Irish nationals living abroad and deciding to return to Ireland, also called returning migration (remigration), to Ireland constituted a steady flow adding an average of 22,000 citizens a year to the total population of the Republic and fluctuating from 16,700 in 2004 to 27,000 in 2002. 2007 marks a record in volume for this group of migrants but the table shows that it occurred within the context of high immigration flows to the Republic, the Irish then only accounting for one immigrant out of five. The 2008 to 2010 period saw all flows, except that of the pre-enlargement Europeans, reduce significantly and the wave of returnees was not different from the general 
pattern. A steady in-coming flow of about 20,000 was maintained for the next two years, nevertheless accounting for just over one immigrant out of three, and then figures dropped again. The 2014 figure is the lowest figure ever recorded for returning Irish migration. Given the estimated size of the Irish diaspora worldwide, the 2014 low figure does not mean that most of those who could or wished to return did so, but rather that the Irish recovery was not yet strong enough a signal to trigger another wave of Irish remigration.

Following the crisis, the most spectacular drop in the number of immigrants was recorded among the post-enlargement Europeans. Here again, following a period of high volumes in 2007, when more than one immigrant out of two originated from the new EU States, flows to more modest in-put into the Irish population were recorded within the next two years and then remained stable. Though the 2014 figure is over eight times inferior to what was recorded in 2007, 10,000 persons on average every year have still reached the Irish shores to become residents every year since 2010. This seems to escape the logic of pure economics as if one is to believe that immigration is mostly related to the economic outlook of the country of destination in 2010 in the Republic, recovery was not even in the offing. Therefore new immigration patterns seem to have started developing. It could be argued that some of these immigrants may have entered the Republic under the family reunification schemes. However, the Irish State has not been the most generous in this respect, despite the efforts of some charities such as The Immigrant Council. Therefore, other motivations must have been at play, and it can be assumed that post-crisis Ireland offered more opportunities to thousands of new EU citizens than what they could avail themselves of in their own country.

Finally, the most unexpected pattern of immigration outlined in the table points to traces the in-coming flows of non-European migrants. Indeed, while their numbers logically shrank reduced immediately after the crisis, as observed for other groups, and, to some extent with the same steep decline between 2008 and 2010, their volumes doubled within the next year, from 2010 to 2011, and then recorded another two-fold increase between 2012 and 2014. So that by the end of the period studied, non-European immigrants represent the largest group of migrants to Ireland, resulting in an entirely new migration pattern wherein linguistic, cultural, religious or other diversity is more than ever present in the Republic. Indeed, Indians were the most numerous applicants, followed by Russian, Chinese and Nigerian citizens. More generally, after the crisis, the continuing in-put of immigrants lessened the effect of increasing emigration thus contributing to a total population growth which remained positive.

The immigrants' age profile shows the extent to which the bulk of immigrants is made up of an adult population. 


\begin{tabular}{|l|c|c|c|c|c|c|c|c|c|}
\hline & 1995 & $\mathrm{M}$ & 2002 & 2006 & 2008 & $\mathrm{M}$ & 2010 & 2014 & $\mathrm{M}$ \\
\hline $0-14$ & $\begin{array}{c}5.3 \\
(17 \%)\end{array}$ & 49 & $\begin{array}{c}7 \\
(10.4 \%)\end{array}$ & $\begin{array}{c}11.5 \\
(10.6 \%)\end{array}$ & $\begin{array}{c}13.9 \\
(12.2 \%)\end{array}$ & 47 & $\begin{array}{c}1.8 \\
(4.3 \%)\end{array}$ & $\begin{array}{c}7.8 \\
(12.8 \%)\end{array}$ & 38.4 \\
\hline $15-24$ & $\begin{array}{c}8 \\
(25.6 \%)\end{array}$ & 40 & $\begin{array}{c}19.8 \\
(29.5 \%)\end{array}$ & $\begin{array}{c}31.6 \\
(29.3 \%)\end{array}$ & $\begin{array}{c}50 \\
(44 \%)\end{array}$ & 46 & $\begin{array}{c}17.3 \\
(41.3 \%)\end{array}$ & $\begin{array}{c}15.9 \\
(26.2 \%)\end{array}$ & 42.7 \\
\hline $25-44$ & $\begin{array}{c}14.6 \\
(46.7 \%)\end{array}$ & 51.3 & $\begin{array}{c}35.2 \\
(52.5 \%)\end{array}$ & $\begin{array}{c}57.2 \\
(53 \%)\end{array}$ & $\begin{array}{c}38.8 \\
(34.1 \%)\end{array}$ & 46 & $\begin{array}{c}18.8 \\
(45 \%)\end{array}$ & $\begin{array}{c}33 \\
(54.4 \%)\end{array}$ & 51.2 \\
\hline $45-64$ & $\begin{array}{c}2.6 \\
(8.3 \%)\end{array}$ & 50 & $\begin{array}{c}4.2 \\
(6.2 \%)\end{array}$ & $\begin{array}{c}6.1 \\
(5.6 \%)\end{array}$ & $\begin{array}{c}7.2 \\
(6.3 \%)\end{array}$ & 58 & $\begin{array}{c}2 \\
(4.7 \%)\end{array}$ & $\begin{array}{c}2.8 \\
(4.6 \%)\end{array}$ & 39.2 \\
\hline $65+$ & $\begin{array}{c}0.7 \\
(2.2 \%)\end{array}$ & 28.5 & $\begin{array}{c}0.8 \\
(1.2 \%)\end{array}$ & $\begin{array}{c}1.4 \\
(1.3 \%)\end{array}$ & $\begin{array}{c}3.6 \\
(3.1 \%)\end{array}$ & 44 & $\begin{array}{c}1.9 \\
(4.5 \%)\end{array}$ & $\begin{array}{c}1.1 \\
(1.8 \%)\end{array}$ & 36.3 \\
\hline Total & $\begin{array}{c}31.2 \\
(100 \%)\end{array}$ & 49.1 & $\begin{array}{c}67 \\
(100 \%)\end{array}$ & $\begin{array}{c}107.8 \\
(100 \%)\end{array}$ & $\begin{array}{c}113.5 \\
(100 \%)\end{array}$ & 47.4 & $\begin{array}{c}41.8 \\
(100 \%)\end{array}$ & $\begin{array}{c}60.6 \\
(100 \%)\end{array}$ & 46.5 \\
\hline
\end{tabular}

** EU 12 until 2013, EU13 for 2014 as Croatia joined the EU in July 2013

Table 9: Age groups of immigrants, (000 persons and \% of total), Male percentages for selected years 1995 to 2014 (Population and Migration Estimates, Table 2, Dublin, Central Statistics Office, August 2013 and 2014)

As can be expected, the 15-44 age groups accounted for eight immigrants out of ten in the 2002-2014 period, a rate hardly higher than in the mid-1990s. It can be assumed that most immigrants intended to enter the Irish labour force; they were therefore adults, some being parents, hence the third highest rate for the 0-14 age group and very few being retirees. The 45-64 age group was underrepresented throughout the period, probably due to the profiles the majority of immigrants are expected to have, where mobility and adaptability prevail over experience. In the immediate aftermath of the crisis, the reduction in volume was most obvious among the youngest, the 15-24 in-coming flows for example have fallen by $65 \%$ between 2008 and 2010, and the decline persisted until 2014. The decrease in the number of immigrants in the $24-44$ age group seemed to have been more temporary as, by 2014 , they returned close to their 2008 volumes and their 2006 share of the immigrant population.

The main impacts of immigration on the Irish population as a whole were first the extension of an already large young adult population. Secondly, throughout the period and as a total of all age groups, female immigrants have been more numerous than male ones, and especially so among young adults. Such a gender imbalance is even more noticeable as there were more male emigrants for the same years, as table 4 indicates.

To know more about these newly settled immigrants, their education attainment and their economic status are some of the social indicators available. 


\begin{tabular}{|l|c|c|c|c|c|c|}
\hline Education & 2009 & 2010 & 2011 & 2012 & 2013 & 2014 \\
\hline Secondary & $\begin{array}{c}21.9 \\
(31.6 \%)\end{array}$ & $\begin{array}{c}15.1 \\
(37.8 \%)\end{array}$ & $\begin{array}{c}17.3 \\
(36.7 \%)\end{array}$ & $\begin{array}{c}14.2 \\
(31.6 \%)\end{array}$ & $\begin{array}{c}14.6 \\
(31.3 \%)\end{array}$ & $\begin{array}{c}13.4 \\
(25.3 \%)\end{array}$ \\
\hline Post Leaving & 6.5 & 2.5 & 5.3 & 3.2 & 2.1 & 3.5 \\
Cert. & $(9.4 \%)$ & $(6.2 \%)$ & $(11.2 \%)$ & $(7.1 \%)$ & $(4.5 \%)$ & $(6.6 \%)$ \\
\hline \multirow{2}{*}{ 3rd level } & 32.5 & 19.5 & 22.4 & 25 & 27.1 & 30.9 \\
& $(47 \%)$ & $(48.8 \%)$ & $(47.5 \%)$ & $(55.6 \%)$ & $(58 \%)$ & $(58.4 \%)$ \\
\hline \multirow{2}{*}{ Not stated } & 8.3 & 2.9 & 2.1 & 2.4 & 2.9 & 5.1 \\
& $(12 \%)$ & $(7.2 \%)$ & $(4.5 \%)$ & $(5.5 \%)$ & $(6.2 \%)$ & $(9.6 \%)$ \\
\hline \multirow{2}{*}{ Total } & 69.2 & 39.9 & 47.1 & 44.9 & 46.6 & 52.9 \\
& $(100 \%)$ & $(100 \%)$ & $(100 \%)$ & $(100 \%)$ & $(100 \%)$ & $(100 \%)$ \\
\hline
\end{tabular}

Table 10: Immigrants' education attainment, aged 15 and over, 2009 to 2014 (000 persons and percentage of the immigrant population) (Population and Migration Estimates, Table 5, Dublin, Central Statistics Office, August 2014)

The table shows that the majority of immigrants over 15 who have settled in Ireland since 2009 received a third level education. This is a proportion similar to that of the Irish-born population according to the 2011 census figures and this population also includes some Irish-born or Irish citizen migrants. There is no doubt that the work-related visa applications for non EU immigrants for example played a selective part in the whole process of immigration. These figures suggest that a majority of immigrants are entitled to qualified jobs in the labour market. However, whether they are offered positions corresponding to their education attainment is obviously not guaranteed. Cases of overqualified migrants occupying underpaid positions were reported in the media at an early stage of the immigration flows and are often due to the length of the process of diploma recognition ${ }^{2}$. The second largest group is made of people who only received secondary education, with a proportion ranging from a third to a quarter of the total immigrant population. For the year 2014 for example, their volumes accounted for a quarter of the total population of immigrants. The low education attainment of this group has a direct impact on their employability in the Republic.

Between 2009 and 2014, the largest group of immigrants was made of individuals at work, whether they found work after their arrival, moved to Ireland to fill a position, came under the terms of a work-permit or became self-employed. Their steady proportion accounted for 42 to $48 \%$ of the total number of immigrants between 2009 and 2014; it reached its lowest level in 2014. The share of unemployed immigrants also remained almost unchanged in the five years fol-

2. As early as 2005, RTE reported on the issues at stake for immigrants' recognition of qualifications and lack of political support. See "Ireland has missed an opportunity" at [http://www.rte.ie/archives/exhibitions/1665immigration/451848-highly-skilled-immigrants-work-in-low-skilled-jobs/], accessed on 5 September 2015. 


\begin{tabular}{|l|c|c|c|c|c|c|c|}
\hline Status & 2009 & 2010 & 2011 & 2012 & 2013 & 2014 & $\mathrm{M}$ \\
\hline At work & $\begin{array}{c}33.7 \\
(48.7 \%)\end{array}$ & $\begin{array}{c}18.4 \\
(46 \%)\end{array}$ & $\begin{array}{c}23.2 \\
(49.2 \%)\end{array}$ & $\begin{array}{c}21.2 \\
(47.2 \%)\end{array}$ & $\begin{array}{c}22.2 \\
(44.4)\end{array}$ & $\begin{array}{c}22.6 \\
(42.7 \%)\end{array}$ & 53.9 \\
\hline Unemployed & $\begin{array}{c}15.7 \\
(22.6 \%)\end{array}$ & $\begin{array}{c}8.5 \\
(21.3 \%)\end{array}$ & $\begin{array}{c}9.7 \\
(20.6 \%)\end{array}$ & $\begin{array}{c}9.3 \\
(20.7 \%)\end{array}$ & $\begin{array}{c}7.5 \\
(21 \%)\end{array}$ & $\begin{array}{c}6.8 \\
(12.8 \%)\end{array}$ & 44.1 \\
\hline Student & $\begin{array}{c}9.8 \\
(14 \%)\end{array}$ & $\begin{array}{c}6.1 \\
(15.2 \%)\end{array}$ & $\begin{array}{c}9 \\
(19 \%)\end{array}$ & $\begin{array}{c}7.3 \\
(16.2 \%)\end{array}$ & $\begin{array}{c}11 \\
(24.5 \%)\end{array}$ & $\begin{array}{c}16.2 \\
(30.6 \%)\end{array}$ & 53 \\
\hline Other & $\begin{array}{c}70.1 \\
(14.5 \%)\end{array}$ & $\begin{array}{c}7 \\
(17.5 \%)\end{array}$ & $\begin{array}{c}5.2 \\
(11 \%)\end{array}$ & $\begin{array}{c}7.1 \\
(15.8 \%)\end{array}$ & $\begin{array}{c}6 \\
(10 \%)\end{array}$ & $\begin{array}{c}7.3 \\
(13.8 \%)\end{array}$ & 20.5 \\
\hline Total & 69.1 & 39.9 & 47.1 & 44.9 & 46.6 & 52.8 & 47.6 \\
\hline
\end{tabular}

Table 11: Immigrant' economic status, aged 15 and over, 2009 to 2014, (000 persons and percentage of the immigrant population) and Male emigrant in 2014 (\%) (Population and Migration Estimates, Table 6, Dublin, Central Statistics Office, August 2014)

lowing the crisis, slightly above one immigrant out of five. In 2014, the jobless category recorded its lowest point, less than $13 \%$ of the total of the 2014 immigrants. This suggests that immigrants' employability and adaptability closely followed the labour market which was viewed as 'recovering' before the end of $2014^{3}$.

The most surprising data the table displays is the surge in the number of students among immigrants in the post-crisis period. Before the crisis, the Irish educational sector had opened up to new non-national potentials. The trend has developed since with the student category coming to represent three immigrants out of 10 in 2014. Further analysis would be needed to determine the share of non-EEA national students and to what extent the setting up of the Internationalisation Register Programme granting, under certain circumstances a Student Immigration Permission, played a part in this increase. Nevertheless a large number of young adults did avail themselves of such opportunities, thus changing the face of migration to Ireland.

\section{Long term impact on the population of the Republic}

As the signs of economic recovery have materialised since 2014, one can wonder what the long term effects of the new migration patterns sketched above will be on the population as a whole.

3. The OECD publication Ireland's Action Plan for Jobs : A Preliminary Review claimed "Ireland's labour market bounced back strongly in 2013" (available at [http://www.oecd.org/ireland/Ireland-action-plan-for-jobs-review. $p d f$, page 1, accessed on 5 September2015) and later The Irish Times hailed labour force strength in early August 2014 under the headline "The economic recovery is most visible in the labour market", The Irish Times, 9 August 2014 (available at [http://www.irishtimes.com/business/economy/the-economic-recovery-is-most-visible-inthe-labour-market-1.1891630], accessed on 5 September 2015). 
There is no denying that the return to high and then persistent volumes of emigration can be accounted for as a loss of human capital, resources and opportunities. Some view the phenomenon as less definitive than what previous generations had experienced, because of a shrinking and globalised world wherein human flows supposedly freely circulate. The losses at home and in the middle term are nonetheless visible.

What is more certain is the de facto diversity the massive and then changing immigration has brought. Beyond the in-coming patterns traced above, the Irish population is now encompassing a multicultural component which could hardly be imagined twenty years ago. From the first sizeable groups of asylum seekers who arrived in the Republic in the late $1990 \mathrm{~s}^{4}$ to the naturalisation ceremonies held on a regular basis 5 , temporary or long term residence has become a reality for thousands of foreigners, introducing a diversity which materialises in many different ways. The economic crisis only impacted a proportion of these individuals. In 2015, the measure of this impact and this diversity relies on imprecise data. Until the next census, in 2016, the exact composition of the population is only based on estimations. These nevertheless allow us to draw the following profile for the period studied.

The composition of the Irish population before and after the crisis has not changed significantly over the twelve-year period presented in the table. Yet, two figures stand out to understand the higher than ever total of $12.2 \%$ of non-nationals residing in the Republic in 2014 and the new diversity that this necessarily brings along. On the one hand, the European post-enlargement citizens remain the most numerous group, reinforcing their presence despite their decline in volume from 2008 to 2014. This is likely to reveal a higher than expected economic sustainability and a more general resilience of this category of residents. On the other hand, almost a third of the non-national residents originate from outside the European Union. This is a major change in the composition of the Irish population as this non-European group of residents gathers over fifty nationalities with various cultures, languages and traditions. The 30\% increase in volume from 2006 to 2014 is a fast growth compared to the Irish growth for the same period. Both phenomena challenge the too-simple assumption that newly settled non-nationals will depart when the economy is ailing. The impact of both

4. The large numbers of applications from 1999 to 2003 do not reflect the effect they had on the population as it is believed that only about $1 \%$ of applications were granted to asylum seekers. But their presence was visible and mediatised.

5. According to the department of Justice and Equality, there were 100 naturalisation ceremonies held in the Republic between June 2011 and January 2015. During these, 59,000 non-nationals became Irish citizens. Source: Irish Naturalisation and Immigration Service, "Minister Fitzgerald attends 100 Citizenship Ceremonies”, 23 January 2015, [http://www.inis.gov.ielen/INIS/Pages/Minister\%20Fitzgerald\%20attends\%20100th\%20 Citizenship\%20Ceremony], accessed on 6 September2015. 
European post-enlargement citizens and non-nationals from further afield seems to be a lasting one.

\begin{tabular}{|l|c|c|c|c|c|}
\hline & 2006 & 2008 & 2010 & $2012^{*}$ & $2014^{*}$ \\
\hline Irish & $3,802.4$ & $3,909.5$ & $3,994.7$ & 4,035 & $4,045.3$ \\
& $(89.8 \%)$ & $(87.1 \%)$ & $(87.7 \%)$ & $87.9 \%)$ & $(87.7 \%)$ \\
\hline \multirow{2}{*}{ UK } & 115.5 & 117.9 & 115.9 & 113 & 114.9 \\
& $(2.7 \%)$ & $(2.6 \%)$ & $(2.5 \%)$ & $(2.4 \%)$ & $(2.4 \%)$ \\
\hline \multirow{2}{*}{ Rest EU15 } & 43.8 & 50.8 & 52.4 & 45.5 & 38.1 \\
& $(1 \%)$ & $(1.1 \%)$ & $(1.1 \%)$ & $(0.9 \%)$ & $(0.8 \%)$ \\
\hline EU12/13 & 132.5 & 247.7 & 233 & 229.4 & 230.7 \\
& $(3.1 \%)$ & $(5.5 \%)$ & $(5.1 \%)$ & $(5 \%)$ & $(5 \%)$ \\
\hline \multirow{2}{*}{ Rest/ world } & 138.8 & 159.2 & 158.7 & 162.5 & 180.5 \\
& $(3.2 \%)$ & $(3.5 \%)$ & $(3.4 \%)$ & $(3.5 \%)$ & $(3.9 \%)$ \\
\hline \multirow{2}{*}{ Total } & $4,232.9$ & $4,485.1$ & $4,554.8$ & $4,585.4$ & $4,609.6$ \\
& $(100 \%)$ & $(100 \%)$ & $(100 \%)$ & $(100 \%)$ & $(100 \%)$ \\
\hline
\end{tabular}

* Preliminary

Table 12: Population classified by nationality, (000 persons and share of the total population in \%), 2006 to 2010, estimates for 2012 and 2014 (Population and Migration Estimates, Table 8, Dublin, Central Statistics Office, September 2012; Population and Migration Estimates, Table 7, Dublin, Central Statistics Office, August 2013; Population and Migration Estimates, Table 9, Dublin, Central Statistics Office, August 2014)

This article has not dealt with illegal migration which is yet another aspect of immigration that the crisis probably affected. By definition this field of study is rather difficult to tackle, as data are not available and very sensitive. Yet, the cases of 18,000 Irish-born children who had at least one illegal parent in 2008 or the Migrant Rights Center Ireland's support for the cases of thousands of vulnerable non-nationals fueling the Irish grey economy ${ }^{6}$ show that they constitute part of the change in the post-crisis Irish demography.

\section{Conclusion}

To conclude, it must be said that the study of emigration from and immigration to Ireland in the post-crisis period not only proves that both inflows and outflows are sensitive to economic downturn but also that such migratory flows change rapidly and sometimes in an independent or anticipatory way in relation to the economic recovery. Indeed, if migrations act as an adjustment mechanism

6. A rally was recently staged in Dublin on March $15^{\text {th }} 2015$ to campaign for the regularisation of many undocumented workers. The supporters claimed that they were demanding the same type of regularisation as the Irish government was asking for its citizens in the US. 
in a crisis period, the fact that emigration continued during the boom period and immigration never stopped during the recession shows that these flows may operate without the expected cause almost always justifying their existence but for other reasons and motivations which require further analysis. In the case of Ireland, falling net migration is mainly due to a labour immigration stream but a more complex attractiveness is also at play, especially for immigrants from non-European countries. The migratory patterns highlighted in this article have simultaneously occurred in some other European countries, Spain and Italy for example, confirming that migrant flows need to be considered internationally and compared. The changes in population composition which result largely from these movements are only sketched out here and not thoroughly covered by the data available, especially so in the intercensal periods. The Irish population has undergone major demographic changes in the past twelve years, in the post-crisis period almost as a boomerang effect to what had happened before and impacting all levels of Ireland's social and cultural fabric. 